\title{
Exploring The Heritage Value of Space in Sang Cipta Rasa Mosque, Keraton Kasepuhan
}

\author{
INA HELENA AGUSTINA \\ Program Studi Perencanaan Wilayah dan Kota, Universitas Islam Bandung \\ Jl. Tamansari No 1 Bandung- 40116, 022-4203368 pswt.204 \\ email: inahelena66@gmail.com
}

\begin{abstract}
Sang Cipta Rasa Mosque is an integral part of Keraton Kasepuhan incorporated within the area as a whole. The Keraton Kasepuhan is located in Cirebon City. Heritage value is an aesthetic value, history, scientific work, and social-spiritual value derived from the long history of historical places (Kalman;2014;200). Sunan Gunung Jati is a historical figure in the spread of Islam as well as a King in Cirebon. "Sang Cipta Rasa" Mosque is a place that becomes a milestone in the spread of Islam by Sunan Gunung Jati. The Mosque is not only a place of worship mandatory for Moslems but also a place of spiritual awakening of the ummah (Agustina; 2015;2016). The spatial viability of the mosque through periods of civilizational changes is a phenomenon subjected as the main interest of this research. This research is part of writer's dissertation using Husserl's phenomenology method implemented in Keraton Kasepuhan. This paper is written as a continuation of the aforementioned previous research, resulting in an in-depth exploration concerning the aesthetic values of spatial symbol of the mosque. The purpose of this paper is to explore the heritage value in Sang Cipta Rasa Mosque. The finding of this research is a construction of perceived heritage value of both macro and micro space of Sang Cipta Rasa Mosque.
\end{abstract}

Keywords: heritage value, space, sang cipta rasa mosque

\section{Introduction}

Mosque has its own significant role in the history of the ummah, epitomized by the life of prophet Muhammad (pbuh) through his deeds in which his preaches, military exercises, diplomacies, gatherings and discussions held within. The Nabawi mosque was the second mosque built by the messenger of Allah after the Quba mosque. It was a milestone for the Islamic world, built in the city of Madinah which was once called "Yastrib". Madinah itself in Arabic means "a place for civilization". Since the time of prophet Muhammad (pbuh), mosque was built as a center of orientation and of Islamic civilization (Madjid 1997-34). Throughout history, mosque has always been playing its important role in contributing to build the life of the ummah. Civilization is a word signifying development (ingenuity \& culture) of nations in the world. Greertz (in Abdullah 2010, 1) stated that civilization is a system of construct inherited in the form of symbols, through which mankind communicate, conserve, and develop knowledge and attitude towards life. It is similar to the Sang Cipta Rasa mosque and its existence as a symbol of triumph in building an Islamic civilization in western part of Java island. It also possesses symbols of aesthetic values and knowledge of the meaning in life as well.

Sang Cipta Rasa mosque was built in 15th century by Wali Sanga (Agustina, 2015). Wali Sanga, who were responsible for the spread of Islamic teachings in Java, sent Sunan Gunung Jati to the western part of the island. Hence, Sang Cipta Rasa mosque is one of the symbols of place where Islam was originally introduced in western part of Java. Apart of being a symbol, the mosque is also a cultural artifact and its existence an embodiment of a collective consciousness of its era. Although it was not the first mosque built in western part of Java (Pejlagrahan mosque was the first to build), nonetheless, Sang Cipta Rasa mosque bears a more

Received: July 25, 2017, Revision: September 14, 2017, Accepted: December 08, 2017

Print ISSN: 0215-8175; Online ISSN: 2303-2499. DOI: http://dx.doi.org/10.29313/mimbar.v33i2.2730.428-438

Accredited B based on the decree No.040/P/2014, valid on February, 18, 2014 until February, 18, 2019. Indexed by DOAJ, Sinta, IPI 
significance due to its size and well-planned arrangement within the area as part of Keraton Kasepuhan. Supposedly, the name "Sang Cipta Rasa" was chosen by taking into account the Hindu-Buddha theology that were once the dominant religions at the time. The process of spreading Islam through acculturation of Hindu-Buddha religions and traditions made Islam gained acceptance with ease from the people. The non-existent of conflict in transformation of religion from Hindu-Buddha to Islam epitomized the success of spreading Islam in western part of Java.

Sang Cipta Rasa mosque was built in the pre-modern era and its existence has endured through the test of time to this day. Withstanding through periods of civilizational changes, its heritage value is something of great interest to be studied, especially from its aesthetic and socio-spiritual standpoint. Furthermore, confronted with the looming threat of globalization and its inevitable effects, the socio-spiritual existence of the mosque hangs in the balance. Globalization gives way to the emergence of electronic space resulting in the disappearance of social and religious values (Abdullah 2010;115). The acceptance and endorsement of different values will not only alter the existing ones but to a an extent could even have a profound impact to social meanings including religion.

A mosque as a spatial means of religious worship has a role in preserving the everlasting values of religion. As well as Sang Cipta Rasa mosque still preserves its spatial existence and religious values through traditional rituals from the pre-modern era that are still in practice at the present time. Sang Cipta Rasa mosque with its historical richness holds its own unique heritage values, ones that need exploring in order to appreciate and preserve. The purpose of this paper is identifying the heritage values of sang Cipta Rasa mosque, notably of its aesthetic and socio-spiritual values.

\section{Methodology}

This paper is part of a research carried out in Keraton Kasepuhan in Cirebon. The research is using the implementation of Husserl's phenomenology in which its methodological approach can infer to meanings (Moustakas, 1994). Phenomenology as a methodological approach tries to perceive meanings from reality. The construct of reality forged through the researcher's perception will infer to meanings from individual experiences. Thereafter, comparing meaning perceived individually by conducting interviews and determining "intersubjective validity" resulting in self-perceived meaning and others'. Description of what the informants (others) perceived is a means to identify the essence derived from the experiences shared in common between the informants and researcher. Essence is derived from the process of epoche, phenomenological reduction, bracketing, and the development of structural synthesis to perceive a deeper meaning.

The analytical process of the research will be implemented as follows: (1) Describing the whole experience from the initial research. The description process is needed in order to gain significant information units as an element of a phenomenon resulting from the Grand Tour. The Grand Tour process is performed by taking into account various phenomena of relational activities concerning individuals, activities that are taking place in space, as well as spaces that have undergone changes due to human activities. (2) Unitization of various descriptions that have already been recorded in logbook. This process will be complemented with textual description from the experiences. (3) Detailing each statement (data horizontalization) and placing statements that have equal value as part of information units categorization process. (4) Categorization process in order to arrange information unit to avoid overlaps and redundancies. (5) Categorization of information units subsequently needed to group information units into specific themes. (6) The process of determining themes is carried out by correlating information units. (7) Validation process through triangulation method by feeding results from specific themes.

This paper is focusing on the spatial exploration of the mosque subsequent to the study of other spaces existing within the area of Keraton Kasepuhan in Cirebon.

\section{Allotment and spatial arrangement of Sang Cipta Rasa mosque}

Sang Cipta Rasa mosque is located to the west of Keraton Kasepuhan square. Keraton Kasepuhan is located to the south of Sang Cipta Rasa mosque, and oriented northward where the graves of the ancestors and royalties lie, including the grave of the venerated Sunan Gunung Jati. 


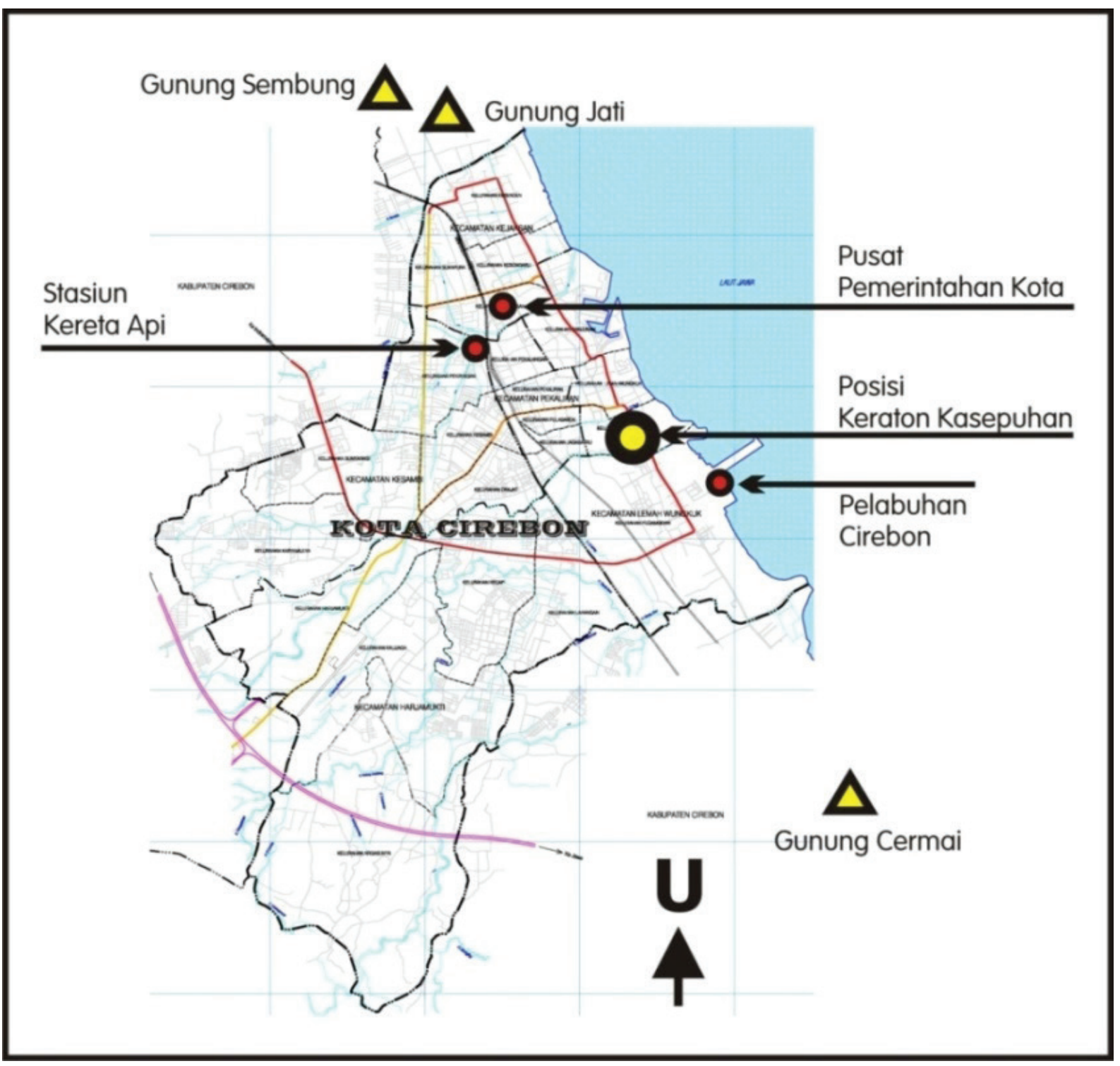

Figure 1. Keraton Kasepuhan Area within the context of its surrounding. Source: Agustina 2014;23.

Depictions are explained through following figures:

Sang Cipta Rasa is a mosque governed under the authority of two ruling powers in Cirebon, namely Keraton Kasepuhan and Keraton Kanoman. Naturally, spatial division was created to provide the needs of the two sides. Prayer rooms for the two are separated by a divider called maksurah. The family of Keraton Kasepuhan occupy the front prayer row to the right of the pulpit while the family of Keraton Kanoman occupy the back prayer row near the entrance door (see figure 3 ). The management of the mosque falls under the responsibility of the stewardship of the mosque community. The administrators of the mosque are appointed by the kings of both
Keraton Kasepuhan and Keraton Kanoman. The administrators of Sang Cipta Rasa mosque are graduates from pesantren (school for Islamic cleric) Buntet. The head of the mosque's administrators is called penghulu masjid (see figure 4). Identity pattern that emerges from the difference of age forms a spatial allocation of which arrangements are played out. The older clerics or "Sepuh" occupy the front row while the younger ones or "Anom" occupy the back; their positions are not parallel to each other but in the opposite side instead; a pattern signifying a balance. The arrangement also sends clear message to the different age groups of their roles and obligations. One group is obliged to give guidance while the other is obliged to follow. The dualistic nature of the two opposing 


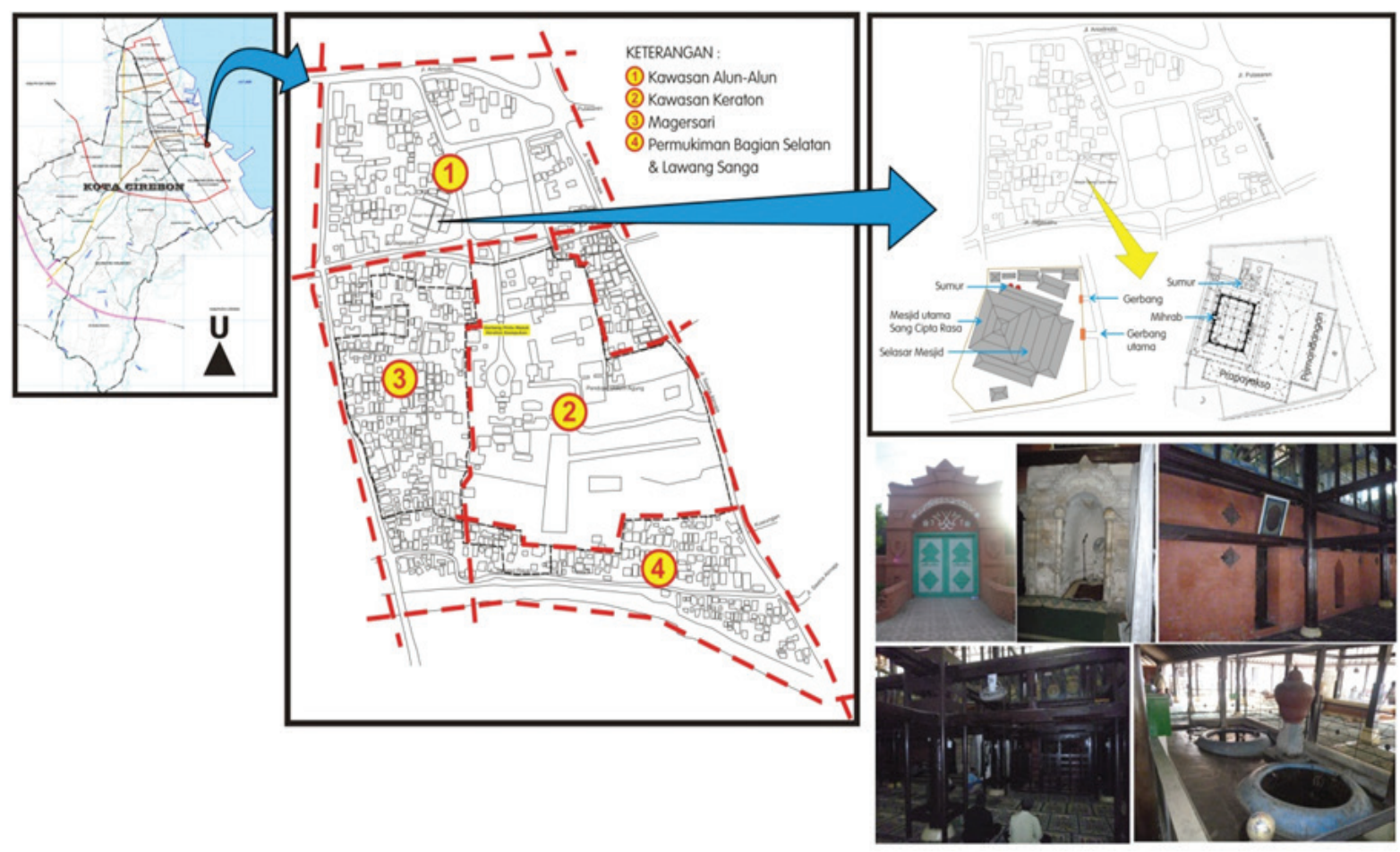

Figure 2. The location of sang Cipta Rasa mosque and pictures of the mosque. Source: Agustina 2015; 111.

groups forms a paradoxical attribute of a unified segregation.

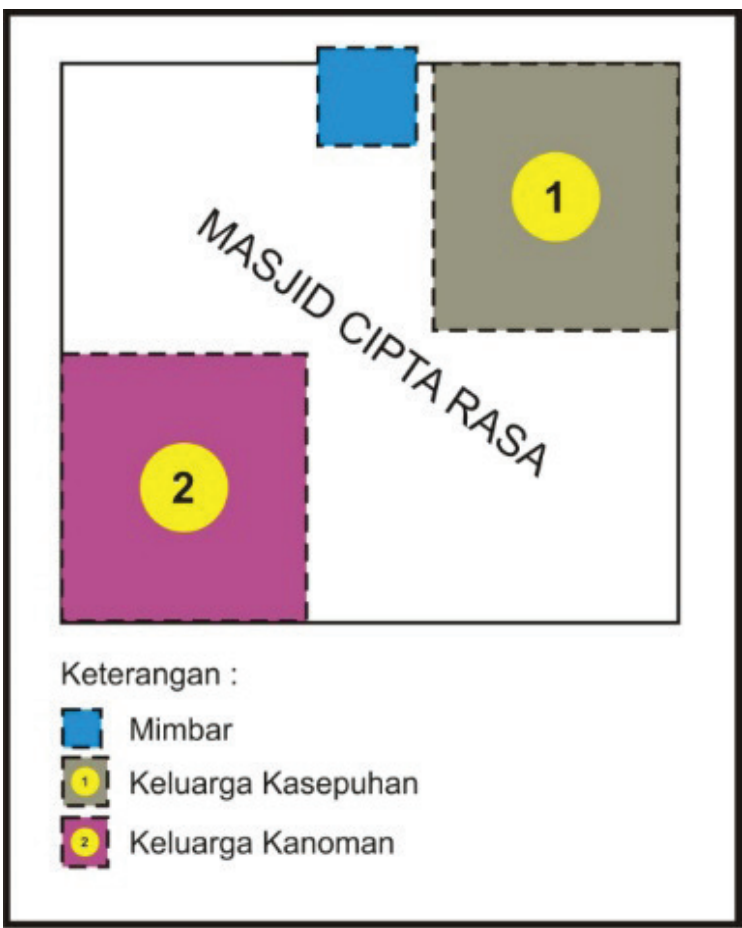

Figure 3. The spatial division of maksurah for Keraton Kasepuhan and Keraton Kanoman.

Source: Agustina 2015;106.

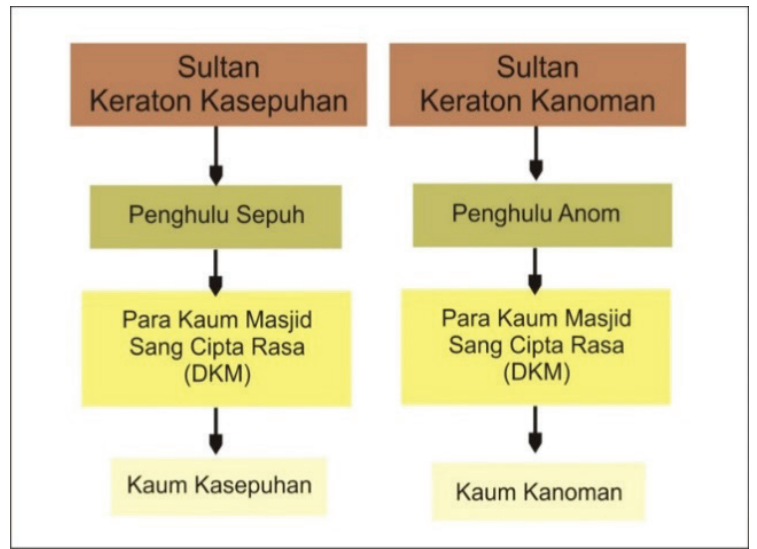

Figure 4. The organizational structure of Sang Cipta Rasa mosque. Source: Agustina 2015;106.

Keraton Kasepuhan and Keraton Kanoman share equal responsibility in preserving the existence of Sang Cipta Rasa mosque. The division in spatial use of the mosque and authority between the two has been in practice since the 16th century. The management of the mosque is based on the policies agreed between the two. The spatial arrangement and policies follow the predefined division of authority (see figure $4)$. The policies from both Keratons are still viable at the present, mainly those regarding 
the management of the mosque and esoteric rituals attended by the people from outside of the Keraton who still believe in the tradition. A tripartite identity pattern manifested consists of the King-Penghulu (Chieftain)-Folk. In addition the role of the chieftain is very important in performing spiritual tradition of the Keraton, a reminder of a traditional societal pattern that is well preserved.

\section{The Mosque as a symbol of paradox in macro space}

Jacob Sumarjo (2014) stated that the Indonesian epistemology takes a different route to that of western philosophy which weighs heavily on the rational cognition. Indonesian epistemology emphasizes on the awareness of perception (awareness of actual-factual acceptance), of experiencing senses, and appreciation of reality. While the subject is being observed, object constitutes of what is perceived by the researcher. This knowledge is considered as a paradox in its nature owing to the fact that even though the dualism between the subject and the object is admittedly accepted, but the subject has become the researcher's external reality of self-consciousness. This also applies as to how the macro space is perceived. A macro space constitutes a larger scope compares to its surroundings. Within the context of macro space, Sang Cipta Rasa mosque is located between Keraton Kasepuhan and Keraton Kanoman, to the west of Keraton square. The

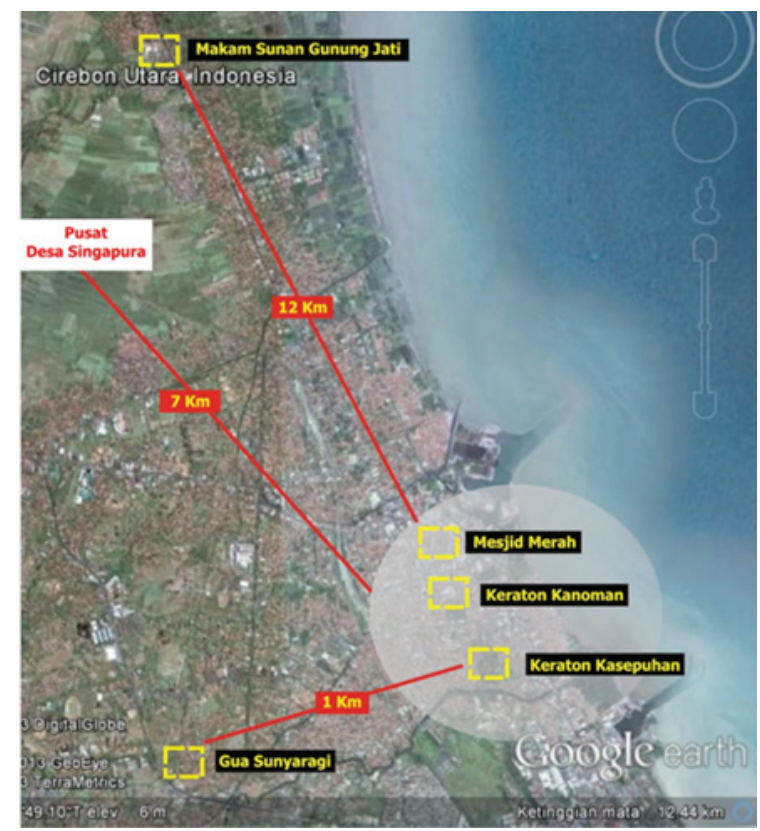

Figure 5. The position of Sang Cipta Rasa mosque in macro space. Source: Agustina, 2013 location of the mosque was not something that is accidentally specified. It is an artifact from a pre-modern era, a result from a well-perceived reality, and an embodiment of belief. The mosque is a religious artifact derived from human mind truthful to the unity of man, deity, and the universe (Sumardjo $2014 ; 7$ ). Accordingly, the location of the mosque is considered as something to be resolved by taking into account its immanent and transcendent attributes.

The position of mosques within the Keraton area indicated by the tajug (a pyramidal square ornament which is usually used for sacred buildings) reveals that Sang Cipta Rasa mosque occupies the outermost part of Keraton area (and as part of Keraton square). It is more spacious and has the biggest tajug compared to other mosques in its surroundings such as Pejaglarah, Dalem Agung, Langgar Alit and the mosques within the Magersari settlement. Sang Cipta Rasa mosque's significance exemplified by its location and its size compared to other surrounding mosques. It also has the right as the only mosque in Keraton area where Friday prayer is being held performed in its own unique traditional way with the adzan (call to prayer) chanted by 7 muazzins. This tradition is well preserved due to the resilience of both Keraton Kasepuhan and Keraton Kanoman. This phenomenon showcases the consistency and commitment of the current ruler in embracing the esoteric tradition of the past passed on through generations to the present time. Beyond just preserving traditions, Sunan Gunung Jati's words of wisdom is still applied, one that said "Ingsun Titipna Tajug Lan Fakir Miskin" which means the entrustment of fate of the mosque and the poor (Agustina 2015) implies a message of immanence rendered in the form of spatial expression and the unity of ummah maintained by Keraton.

Sang Cipta Rasa mosque has a deeper spatial meaning, as its space accommodates dualities, as primordial cultures form an interplay between dualities (Sumardjo $2014 ; 14)$. The mosque functions as a spiritual center (heavenly in nature) adjoined with Keraton which is the center of government and ruling power (worldly in nature) of the past. This conveys a paradox that has its own authentic attributes. A calling to live a life in whole and in a harmonious unity between macrocosmos and meta-cosmos. As Sunan Gunung Jati's message "IngsunTitipnaTajug Lan Fakir Miskin" implies duality where "tajug" represents the spiritual realm while 
"fakir miskin" (the impoverished) is an actual worldly matter.

\section{The Mosque as a symbol of paradox in micro space}

Symbol is a reality, one that connects mankind to a higher being the almighty (Sumardjo;2014). Sang Cipta Rasa mosque possesses symbols with symmetrical arrangement, the symbol of the mosque's establishment is one example. The exact construction date of the mosque is uncertain, but Keraton tradition suggests that the mosque was built in the year 1480 under the initiative of Nyi Ratu Pangkuwati with the help of Wali Sanga and some experts from Demak by Raden Patah. While another source suggests that the mosque was built in 1422 year of Caka or 1500 AD.

This information is taken from Candrasangkala (a coded sign or writing containing information about a particular year in the form of a password/order of words creating a new meaning) etched in front of the mosque. The establishment of the mosque is informed discreetly through the association of words and numbers. The coded words of Candrasangkala are as follows: Waspada Panenbehe Yuganing Ratu. The numbers associated with the words are as follows: Waspada equals 2, Panenbehe equals 2, Yuga equals 4 and Ratu equals 1 . The numbers then to be re-arranged in reverse fashion to form the information about the year the mosque was built which is 1422 . The use of Candrasangkala suggests that the number refers to 1422 year of Caka or 1500 $A D$ in Gregorian calendar year.Based on the indigenous Cirebonese oral traditions, Sang Cipta Rasa is one of the oldest mosque in Java, on par with Masjid Agung Demak (Agustina $2015 ; 100)$.

The mosque takes form of a square oriented to Ka'bah 30 degrees North-West (see figure 6). The mosque was built to accommodate the growth of various Islamic activities from the ummah since Tajug Pejalagrahan could no longer facilitate them due to its limitation in size. Reportedly, the mosque was one of the places for meetings by Wali Sanga, the Islamic missionaries in Java. There are 9 doors to enter inside the mosque. The main entrance is located to the east while the rest are located to the south and the north. The total number of doors represents the 9 Islamic missionaries in Java or Wali Sanga. At the pulpit of the mosque, there is an engraving of a lotus flower right where the Imam use to stand. According to oral tradition, the lotus engraving was made by Sunan Gunung Jati symbolizing Huyyunilarahin (life without spirit). The lotus symbol ubiquitous presence is seen in the buildings inside Keraton Kasepuhan (Agustina, 2017). There are also 3 floor tiles that have special markings associated to their traditional value. The 3 tiles are dedicated to 3 members of Wali Sanga, namely Sunan Gunung Jati, Sunan Bonang, and Sunan Kalijaga. According to what the indigenous people believe, the tiles symbolize Islamic teachings; Iman, Islam and Ihsan (Agustina 2015;104). Sang Cipta Rasa mosque no longer put Mastaka/Mamolo (A roof decoration place at the top as the head of the building, once believed to have a sacred attribute) due to events happened in the past believed to have a bad influence to the ummah. Symmetry is the norm of the mosque, it not only reigns in the shape of the building but also in the expression of its symbols.

If seen in Figure 6 then the shape of the mosque building is symmetrical. The symmetrical pattern is not only in the shape of the building but the symbols of the mosque reveal symmetrical patterns. Further explanation of these symbols can be followed in the following sections.

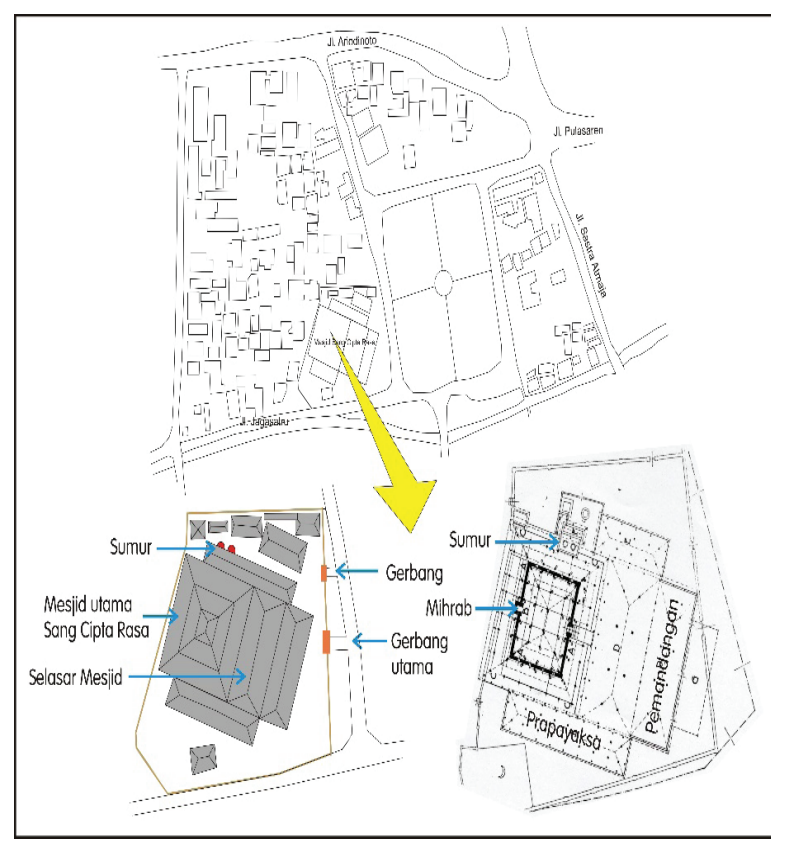

Figure 6. Sang Cipta Rasa mosque, view from above.

Source: Agustina, 2013. 


\section{Aesthetical explanation of symbols in Sang Cipta Rasa mosque}

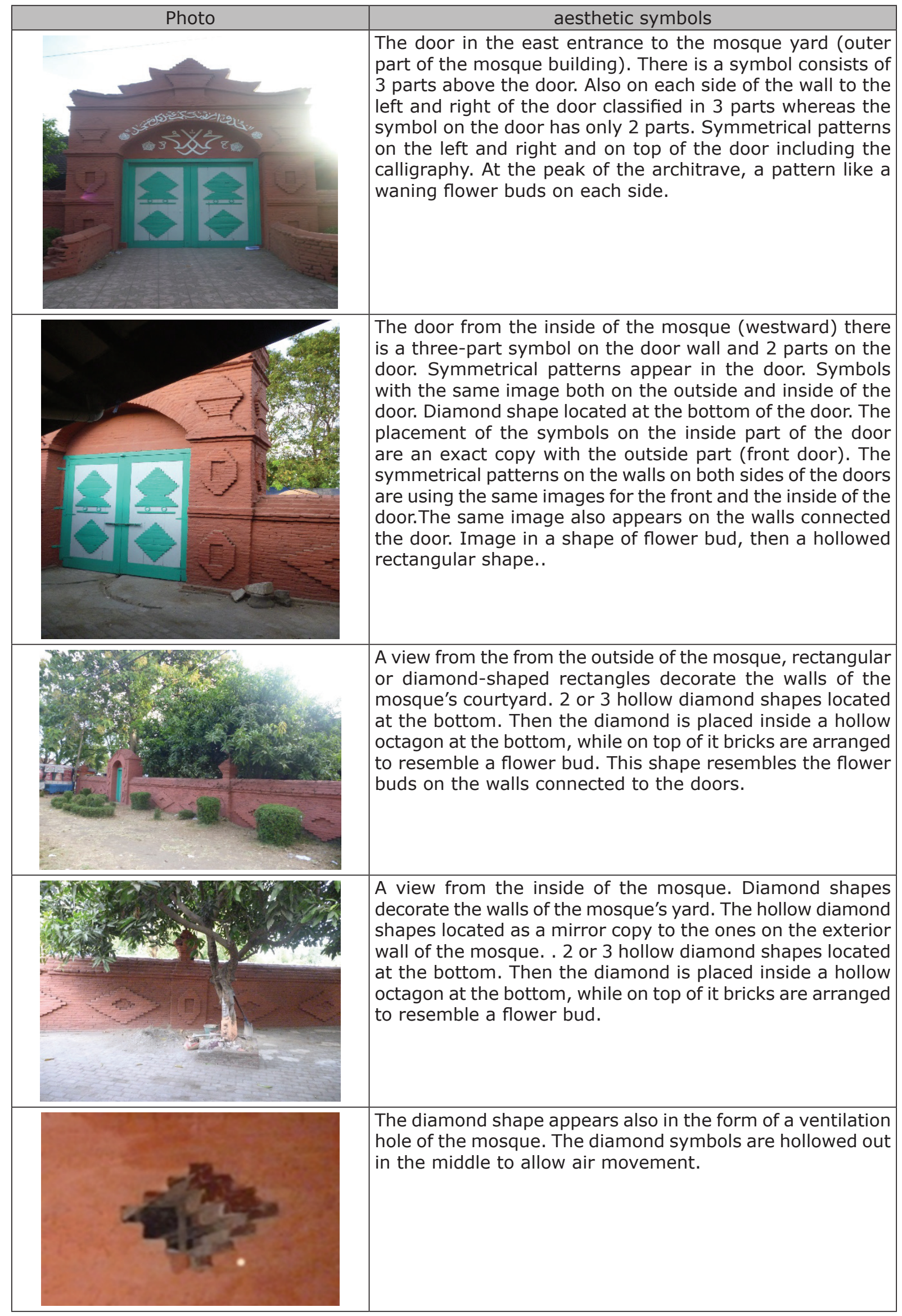




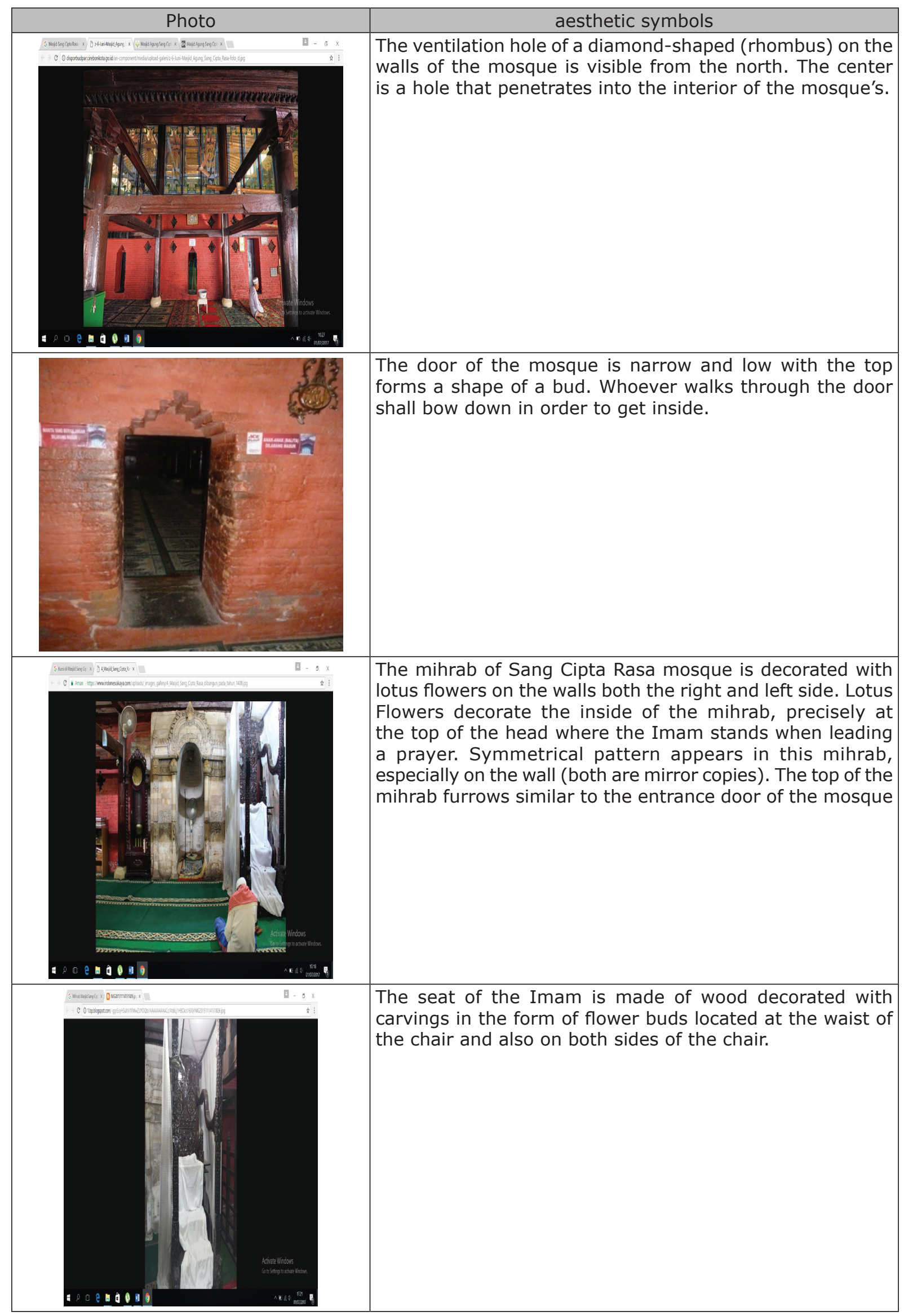




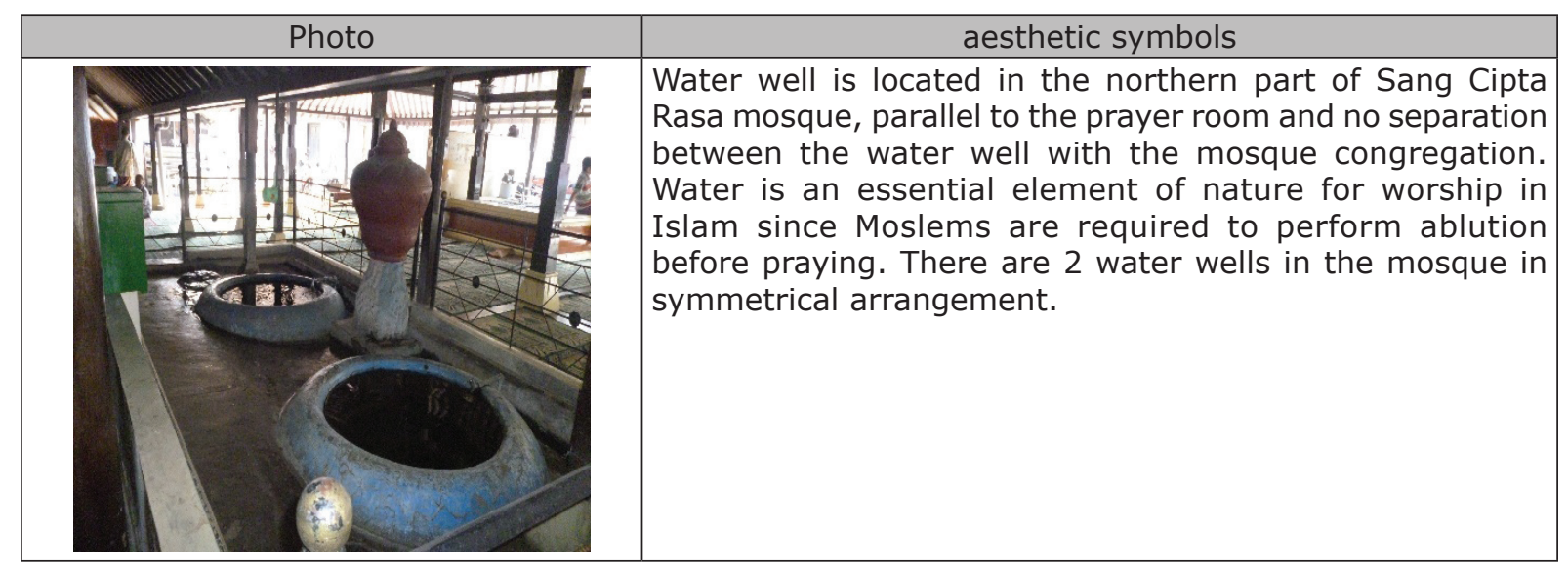

Source: Agustina, 2017.

Aesthetic symbol of Sang Cipta Rasa Mosque is seen on the symbol of lotus flower in mihrab, the entrance that furrows at the top. The lotus symbols are also located on the mihrab wall, inside the mihrab (where Imam stands) and the pulpit seat. The lotus is a symbol of the universe, water wells are positioned on the same level with the floor of the mosque, water is the source of life and as a medium for lotus flowers to grow. While the lotus flower has eight petals that is an analogy of 8 directions in compass. In addition to the lotus flowers there are three-part patterns in the Rasa Cipta Rasa Mosque i.e. the three-part pattern at the front entrance of the Mosque, three-part (top-middlebottom) pattern in the mihrab, three-part pattern (Iman-Islam-Ihsan) on the mosque floor. Another significant pattern apart from to the three-part pattern is the symmetrical pattern seen from several symbols on the door, mihrab, and the walls of the mosque's courtyard and the mosque building layout. Diamon pattern appears in the vents of the mosque, door, and the wall of the courtyard. An octagonal pattern appears on the walls of the courtyard and the entrance. The diamond symbol gives meaning to the cosmic pattern of heaven, earth, land and sea (Sumardjo $2014 ; 254)$. These symbols have a meaning that relates to the universe as well as to God Almighty. In its entirety, Sang Cipta Rasa mosques is a symbol of macrocosmos, microcosmos, as well as meta-cosmos (the unseen realm).

\section{The Construct of Spatial Heritage Value of Sang Cipta Rasa Mosque}

Apart from having symbols from the past, the mosque is a place to perform esoteric traditions, attractions that has become the pulling factor of the mosque.
Keraton's esoteric traditions become a shared value system that binds different communities that are spatially and socially segregated (Agustina, 2014; 108). The concept of esoteric tradition performed in a contemplative practice invites the public to substantively build their inner spiritual awareness (Agustina, 2016). Esoteric traditions that take place in Keraton Kasepuhan are the Jumat Kliwon Tradition, Panjang Jimat Tradition, Haul Tradition and other traditions scheduled according to the Islamic Hijriyah calendar. Of those, esoteric traditions that have the highest appeal to public are the Jumat Kliwon tradition and Panjang Jimat tradition. Participants of the traditions come from many different regions across Cirebon's administrative area to be a part of mass contemplative rituals. They believe in gaining inner peace from such practice. From a modern perspective, their behaviour can be considered unrational. Nonetheless, this phenomenon is the reflection of reality in exhibiting the community's spiritual behaviour. The practice of the tradition leads to a spiritual reflection that transcends time and space. People who have lived this tradition for most of their lives gained spontaneous enlightenment from their reflective behavior. Naturally, a spiritual experience is the aim of this traditional practice. The spontaneous enlightenment gained from such rituals occurs beyond human understanding of the law of causality. These rituals are simply irrational from the view of the modern world. The practice takes a lot of discipline from dzikir (a form of praying by recitation in repetitions) all night long, pilgrimage to the grave of Sunan Gunung Jati by walking from where they live, to fasting and nyepi (khalat). This practice is called mysticism (tasawwuf) a very personal take on the psychological and spiritual needs of tranquility (Zaehner, 
2004).The goal is to reach the state of sufism, self detachment from the worldly, the understanding of self, separation from all created beings and submission to god. According to Al Junaid (orthodox sufism), sufism is being a confidant of god without any additional instrument (Zaehner, 2004;7). Performers perceive inner peace by executing the rites. Such reflective spiritual behaviour perceived repeatedly and inherited through many generations taking place in Sang Cipta Rasa mosque. Understanding such behaviour is beyond human's ability to rationalize.

The ritual of esoteric tradition is derived from the pre-modern era when Islam was first introduced by Sunan Gunung Jati. Ernst Cassier regarded the pre-modern era as the age of deity, the epoch of gods and goddesses, a divine world (Sumardjo, 2014;335).

Every religious tradition has its own unique form of spirituality, where spirituality is not something peripheral. Contrary, it is the essence and substance of every religion (Izutsu, 2015). Similarly, the esoteric traditions performed in Sang Cipta Rasa mosque transmit the essence of spirituality that expresses an awareness of the divine or the truth (Al Haqq) and admittance to His being. According to Imam Al Ghazali, the basic needs of every human being consist of 5 things, namely ( 1 ) religious needs (al dien), (2) the needs of the soul (nafs), (3) the needs of reason (aql), (4) the needs to have offsprings (nafs), (5) the needs of property (maal) (Amaliah, et al; 2015;43).The esoteric traditions held in the mosque is a way to fulfill the human needs of the soul (nafs), thus the esoteric tradition endures to the present time due to the "peace of mind" it brings to those who follows the practice (Agustina, 2016). The esoteric traditions deliver transcendent values into actualization of spirituality and bring into existence the belief in god. The performers of the traditions offer themselves as concrete objects to discover the nature of "being". Such spiritual practice is a means of unification with the "Supreme Being". To arrive to this stage, they need to eliminate their ego. The emptying one self from ego is a process of admittance, of allowing the "Supreme Being" into one's soul. Therefore, esoteric traditions such as Jumat Kliwon and others like it held in Sang Cipta Rasa mosque, are activities transcendent in their nature.

The act of transcendency in which the emptying of mind by performing rituals of dzikir, reminding one self perpetually of Allah, associated with the notion by Danah Zohar (in Armahedi Mahzar, 2004;53), that the true emptiness is not empty at all, but a state of fullness, brimful of pure energy. The kind of energy that is divine in nature, in which case human being that reaches to such level is directly connected with the immanent God. Hence, peace of mind is gained through such connectedness with the divine. This event became the rational basis for the foundation of transcendent behavior by the tradition performers.

Heritage value is an aesthetic, historical, scientific, and socio-spiritual value derived from the chronicles of historical places (Kalman, 2014, 200). Based on the above explanation, heritage value of Sang Cipta Rasa mosque is not only perceived solely from the physical space, but also from the activities taking place i.e. esoteric traditions that accommodates the immanence of God perceived by the performers. Thus the construct of heritage value of Sang Cipta Rasa mosque can be described into the following (see table 1 ). Heritage value as a form of local genius, where local genius plays an important role for the development of culture in society (Irmayani, 2015, 475). Therefore the construct of heritage value of Sang Cipta Rasa mosque can be utilized as a reference and consideration in the development of the mosque and the surrounding area.

\footnotetext{
Space Signifier

Construct of heritage Value

Macro Space • Sang Cipta Rasa mosque in an integral part • Center of spirituality and the within the area of Keraton Kasepuhan propagation of Sunan Gunung

- Sang Cipta Rasa mosque plays its role as Jati's message. the main building for worship

- Symbol of Unity and words of wisdom from Sunan Gunung Jati "Ingsun Tititipna Tajug Lan Fakir Miskin"

- The Symbol of Tripartite Affirmation: Chieftain - King - People.
} 
Micro Space - Space with the symbols of diamonds, • octagons, lotus flowers, and water element

- Space with three-part, symmetrical pattern -

- The place where esoteric traditions take place
Unity of microcosm-macrocosm and metacosm

Accommodates immanence and transcendence

\section{Conclusions}

Heritage value of Sang Cipta Rasa mosque comes into existence in the form of a construct that materializes in the application of space, signifiers and traditional values. This can only be realized on account to the mosque being an integral part of its past, especially the ever-present figure of Sunan Gunung Jati and the role of Keraton Kasepuhan in Cirebon. Heritage value in physical form created from the formation of macro and micro space in the area of the mosque and also from the signs in the form of symbols, mosque ornaments and position. Aesthetic values that appear both in the macro and micro space in the area take in the form of symbols with meanings that emphasizes on the spirituality of Islamic religion in the past and has managed to endure to the present time. It is as if the wave of spiritual energy from the past resonates through the passage of time and continues to survive in the mosque. Those who take part in keeping alive the traditions bear testimony to the timelessness of the spirituality of the place. Sang Cipta Rasa mosque is a form of physical space that accommodates the immanence of god while esoteric tradition is a transcendent activity of the performers. The preservation of the value system is a form of a paradoxical aesthetics created from two existing dualistic powers of human and God. All the symbols attributed to the mosque area immanent force of its constituents. The symbols are created out of the religiosity of its creators in the era and their aspirations remain intact to this day. Sang Cipta Rasa mosque has a distinctive value compared to the surrounding mosques and even modern mosques nowadays due to the fact that its symbols are the hallmark of sacredness and unity with the divine. A mosque that survives with the spirit of its creators. The space in Sang Cipta Rasa mosque is a unity between the microcosm-macrocosm and metacosm.

Suggestion from the writer is to preserve the symbols in each and every cultural tourist destination in Cirebon city. The symbols must be in unison with the building codes whether concerning the area of the Keraton or in a larger extent, other buildings in Cirebon city. Preserving the esoteric traditions that take place in the mosque since they give spiritual benefits and fostering wholeness for those who take part. That is also the case regarding spatial symbols, encourage preservation, and publications of their values and the meanings they contain for the benefit of everyone's concern.

\section{References}

Abdullah, I. (2010). "Konstruksi dan Reproduksi Kebudayaan," Yogyakarta, Pustaka Pelajar.

Agustina, Djunaedi, et.al. (2013), "Gerak Ruang Kawasan Keraton Kasepuhan," Jurnal PWK Volume 13 No 1. P 11-17.

Agustina, Djunaedi, et.al.(2014), "Kajian Fenomena Lokal: Model Siklus Perubahan ruang Tradisi Panjang Jimat Kawasan Keraton Kasepuhan, " Proceeding Seminar Nasional Menciptakan Nilai Tambah Dalam Pembangunan Berkelanjutan", Bandung, Fakultas Teknik UNISBA, P22-32.

Agustina, Hindersah, et.al. (2014), "Kajian Makna Ruang Tradisi Esoterik Kawasan Keraton Kasepuhan Cirebon," Bandung, Proceeding SNAPP-LPPM-UNISBA, P 108119.

Agustina, Ina Helena, (2015), "Pergeseran Makna Ruang Simbolik Ke Ruang Pragmatis Kawasan Keraton Kasepuhan Cirebon," Yogyakarta, Program Pasca Sarjana UGM.

Agustina, Helena, et.al. (2016). "Spatial Constructs of Spiritual Consciousness: The case of Keraton Kasepuhan in Cirebon, Indonesia" (svshome.com/pdf/ISVS_4-2).

Agustina, Helena, et.al, (2017), "Identifikasi simbol-simbol Keraton Kasepuhan," Jurnal Ethos, P.292-298.

Amaliah, Julia, et.al. (2015), "Etika Konstruksi Islami dari Pegawai SMU di Kota Bandung," MIMBAR, Vol 31, No 1, P 41-50.

Irmayani, Tengku, Nurbani, Sabariah Bangun (2015), "Local Genius dan Implementasi Pengarusutamaan Gender pada pemerintah Kabupaten Sumatera Utara," MIMBAR, Vol 31, No 2, P 475 -484.

Kalman, Harold , (2014), "Heritage Planning Pripciples and Process," London \& New York, Routledge.

Mahzar, Armahedi, (2004). "Merumuskan Paradigma Sains dan Teknologi Islami," Bandung, Mizan.

Moustakas, C. (1994). "Phenomenological Research Methods," Sage Publications. London.

Izutsu, Toshihiko, (2015), "Taoisme," Bandung, Mizan.

Sumardjo, J. (2014), "Estetika Paradoks", Bandung, Kelir.

Zaehner, R.C. (1994), "Mistisisme Hindu Muslim", Yogyakarta, LKIS. 